Portland State University

PDXScholar

6-6-1972

\title{
The Behavior of Coalitions as Interorganizational Structures: an Exploratory Study Using a Grounded Theory Approach
}

Elaine Marie Rothrock

Portland State University

Follow this and additional works at: https://pdxscholar.library.pdx.edu/open_access_etds

Part of the Industrial and Organizational Psychology Commons, Organization Development Commons, and the Social Welfare Commons

Let us know how access to this document benefits you.

\section{Recommended Citation}

Rothrock, Elaine Marie, "The Behavior of Coalitions as Interorganizational Structures: an Exploratory Study Using a Grounded Theory Approach" (1972). Dissertations and Theses. Paper 1616.

https://doi.org/10.15760/etd.1615

This Thesis is brought to you for free and open access. It has been accepted for inclusion in Dissertations and Theses by an authorized administrator of PDXScholar. Please contact us if we can make this document more accessible: pdxscholar@pdx.edu. 
THE BEHAVIOR OF COALITIONS AS INTERORGANIZATIONAL STRUCTURES: AN EXPLORATORY STUDY USING A GROUNDED THEORY APPROACH

by

ELAINE MARIE ROTHROCK

A report submitted in partial fulfiliment of the requirements for the degree of

\author{
MASTER OF \\ SOCIAL WORK
}

Portland State University

1972 
Applooved by Advisor

Approved by Ad/fisor $\frac{6 / 7 / 72}{\text { Date }}$

$6 / 7 / 72$ 


\section{TABLE OF CONTENTS}

SECTION I.

The Setting of the Study - - - - - - - - 1

The Focus of the Study - - - - - - - - 2

The Rationale for Studying Coalitions - - - - 3

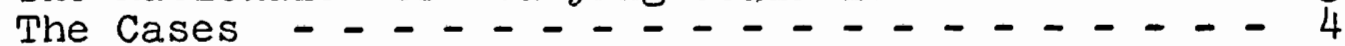

The Methodology - - - - - - - - - - 9

Reporting the Study - - . - - - - - - 14

Limitations and Delimitations of the Study - - - 15

SECTION II

Analytical Categories or Variables - - - - - 17

Comparison of Coalitional Behaviors by

Analytical Categories - - - - - - - - - 21

SECTION III

Generalized Relationships - - - - - - - 29

SECTION IV

Issues for Future Research - - - - - - - - 37

Further Issues for Possible Exploration - - - 40

BIBLIOGRAPHY - - - - - - - - - - - 42

\section{APPENDICES}

Appendix A: Interview Guidelines - - - - - 43 Appendix B: List of Additional Identified Variables or Analytical Categories - - 45 


\section{SECTION I}

THE SETTING OF THE STUDY

This study is one of four exploratory studies concerned with coalitions of organizations that are formed to plan and develop social welfare programs within the local community. Although each study was conducted independently, taken together their major purpose was to develop some insights and knowledge into the behavior of organizations and the ways in which they interact as they work together to develop community programs. They are, then, exploratory studies of interorganizational behavior.

Each of the studies had a different focus. One study attempted to identify the present areas of agreement and disagreement regaraing interorganization behavior by systematically reviewing the literature over the past ten years. Another focused on the stages of development of the coalition, attempting to determine if organizational coalitions seemed to follow similar developmental patterns as has been reported in the literature on small groups. Another focused on the decision-making patterns in the coalitions by first reviewing the literature and constructing a decisionmaking model and then "testing" the model against a set of case histories. This study, following a grounded theory approach, attempted to identify a set of common variables or analytical categories which seemed to be 
present in a number of coalitions. Although each of these exploratory studies was conducted independently with a different emphasis and analytical focus, they each utilized the same set of case histories of coalitions. Consequently, each of the studies utilized a common set of data but viewed the data from quite different analytical perspectives.

THE FOCUS OF THE STUDY

The particular focus of this study is on data-based variables or categories that seemed to appear across coalitions. More specifically, the study explored to what extent cross-coalition variables can be defined and hypotheses or generalized relationships between the variables can then be generated. Further, this exploration was carried out through a process of analyzing research data from a set of case studies instead of from literature. This approach was chosen with the idea that the variables or analytic categories and hypotheses developed by this grounded-theory process could possibly become some of the components of later development of coalitional behavior theory.

The objectives of this study are: (1) to identify, define, and describe variables or analytical categories which appear to be generalizable from the data in a set of case studies of coalitions, and (2) to determine to what extent hypotheses or generalized relationships between the variables can be generated from the case studies data. 
THE RATIONALE FOR STUDYING COALITIONS

There is nothing new about the concept of a coalition of organizations. Organizational coalitions have been formed and reformed ever since man began working through organizational structures. They are common, everyday occurrences, yet surprisingly little is known about them since much of the theoretical work has focused on coalitions of individuals or small groups or on the alliances and coalitions of political groups and nations. Surprisingly little work has been done specifically on organizational coalitions.

A coalition of organizations is an interorganizational structure. That is, it is a structure in which two or more organizations deliberately relate their behavior to each other, as when several organizations jointly agree to plan some new program in the community. They are also unique structures in that each of the organizations maintains its own autonomy, but for a period of time they work together around some common issue or mutual problem.

Coalitions, in contrast to other types of interorganizational structures such as councils or federations, tend to be ad hoc and issue-oriented structures. That is, there is little permanence to the structure. A group of organizations join together around an issue, meet for a period of time, and simply disband or dissolve once the issue is resolved. They are rather fluid and 
amorphous structures but they do represent one of the ways that organizations cooperate with each other. Within recent years the coalition has been viewed as a possible means to coordinate disparate programs within the community. The nffice of Economic Opportunity and the United Way of America have jointly sponsored a project to examine the use of coalitions in the planning process. To some degree, then, the coalition seems to be an increasingly important structure and one that needs to be fully understood by the planner if it is to be effectively utilized.

Consequently, an increased knowledge of organizational behavior, especially on the relationship between organizations, would not only aid the planner in his daily tasks but at the same time contribute to the limited knowledge or interorganizational behavior.

\section{THE CASES}

The case studies utilized for analysis in this study are the results of research carried out on actual coalitions by other graduate students for a class. Their work consisted of interviewing "key" participants in the coalition as well as collecting any written documents pertaining to the coalition, from which the coalition's events and processes were reconstructed as accurately as possible. The interview guideline used by these students is attached in Appendix A. Therefore, 
with the work of data collection already completed, the emphasis of this study was on the analysis and synthesis of the data instead of the collection of additional data.

Following are brief summaries of the four case studies of actual coalitions with which this study is concerned. In this study the names of people and organizations involved in the coalitions have been disguised to protect the confidentiality of the real participants.

Coalition I: "Com-Line"

"Com-Line" was a project to encourage better communication between "pre-alierated" youth and their families through drop-in centers that were open in the evening in the high schools. The coalition which developed the project consisted of three sectarian and one non-sectarian family-service agencies, a faculty member from a graduate school of social work, and a physician who had done much work with alienated youth through a drop-in store-front socio/medical aid station. All of these people agreed on the need for a preventive project involving "pre-alienated" youth and their families. Each of the coalition participants needed the others in order to develop the project -- each was able to provide some combination of needed commodities, e.g. staff time, money, credibility/respectability, access 
to necessary outside groups, helpful knowledge and ideas. The coalition wrote a proposal to have the project, in the high schools, which the school board originally rejected. After some informal attempts by various coalition members to influence school board members, the school board accepted the proposal. The coalition then formalized its structure and operated an initial "Com-line" project.

Coalition II: Child Development Proposal

The Executive Director of a metropolitan-wide child care agency was informed that federal money was available for funding certain child care programs that met specified guidelines. The Executive Director then invited virtually all the various children's services organizations in the city to a meeting to discuss whether or not they desired to write a proposal for such a program, given the extremely limited time deadline under which they would be working. After the group agreed that they did want to proceed, five people became the working committee to draft the proposal. This committee included the Executive Director who had convened the original meeting, a staff member from the Retarded Children's Agency, a psychiatrist from a Children's Clinic, and a staff member from the Medical School's Child Psychiatric Department. A conflict immediately developed between the Poverty Program representative 
and the child care program Executive Director, both of whom wanted their agency to be the sponsoring agency for the proposed program. Several of the committee members were antagonized by the Executive Director's actions strongly promoting the child care agency's interests both in and out of committee meetings. After several other attempts to resolve the conflict failed, the committee finally voted that the Community Action Poverty Program be the formal agent on the grant application. Shortly after this, the child care agency's Executive Director ceased participating in the coalition, and the rest of the working committee completed the final draft of the project for submission for funding.

Coalition III: Iegislative Information Coordination Project

This coalition was the result of a Legal Aid attorney's idea for gaining support for proposed social legislation that his agency was drafting to bring before the Oregon Iegislative Assembly. The coalition consisted of a variety of anti-poverty and social welfare organizations. From this large group a seven-member planning committee informally developed. The committee organized and began actually operating the Project while the coalition of organizations was still being formed. The Project, which had originally been conceived of as performing.a function of advocacy, became a neutral coordinator and facilitator for the exchange of information. To operate 
the Iegislative Information Coordination Project, the coaltion formalized itself and selected a highly respected and neutral person from outside the coalition to be the chairman and public spokesman. The Project was operated with varying degrees of success during the time that the Legislative Assembly was in session.

Coalition IV: Planning for a Mental Health Service System in a Community

This coalition formed in order to develop plans for a system to deliver essential mental health services to a geographic portion of a metropolitan area. The coalition initially was developed from the efforts of a small group of mental health professionals who had been working together on the issue of mental health services for several jears. This group called a meeting of key people in agencies serving the target area to discuss whether or not to submit a proposal to obtain federal funding for mental health services for this target community. The agency people agreed to proceed on the proposal application and also agreed to name one or more persons to represent their agency in the coalition to develop the plans. The original small group of professionals then became part of the coalition of 48 people from 25 agencies. A wide range of organizations concerned with mental health was represented, including church action groups, mental health clinics, public 
health and mental health agencies from the county and state, hospitais, community action agencies, visiting nurses association, a social work graduate school, public welfare commission, juvenile and domestic relations courts, a medical school, and others. The coalition divided itself into eight working committees, each focusing on a different aspect of mental health services. After several months of committee work, an important two-day work conference was held. Conference participants developed objectives, operating guidelines, and an organizational structure for the community's mental health service delivery system. At this point in the coalition's planning process the case study ended.

\section{THE METHODOLOGY}

In many exploratory studies the emphasis is on the discovery of ideas and insights to become more familiar with a phenomenon, often in order to develop a hypothesis or a more specific problem for future research.

Occasionally there is a tendency to underestimate the importance of exploratory research and to regard only experimental ("deductive") work as 'scientific.' However, if experimental work is to have either theoretical or social value, it must be relevant to broader issues than those posed in the experiment. Such relevance can result only from adequate exploration of the dimensions of the problem with which the research is attempting to deal."

(Sellitz, Jahoda, Deutsch, and Cook, 1959, pp. 50-52) 
The preceding rationale for exploratory studies is quite compatible with Glaser's and Strauss' idea of "grounded theory." These authors speak of the development of a theory "from the ground up" as being the discovery of theory from data which has been systematically obtained and analyzed during social research. (Glaser and Strauss, 1967, p. 1). Glaser and Strauss suggest that the elements of grounded theory which will be generated by comparative analysis of the data are 1) conceptual categories and conceptual properties of those categories, and 2) hypotheses or generalized relations among the categories and their properties. (Glaser and Strauss, 1967, p. 35).

The above ideas would indicate that before attempting to develop any valid comprehensive theory of the behavior of interorganizational coalitions, it is useful (and perhaps necessary) first to identify as many as possible of the variables affecting the functioning of coalitions. Therefore, instead of first developing as many potential variables as possible from the literature and/or from logic and then checking them with real data, this study followed the reverse procedure. Briefly, this procedure consisted of analyzing the case studies, and then checking the data-based variables and hypotheses with related literature. The analytical categories identified by this approach can then contribute to developing 
theories of coalitional behavior "from the ground up", so to speak, in a manner consistent with the ideas of both Seliltz et $\underline{\text { al }}$ and Glaser and Strauss.

As previously noted, the objectives of this study are: 1) to identify, define, and describe variables or analytical categories which appear to be generalizable from the data in a set of case studies of coalitions, and 2) to determine to what extent hypotheses or generalized relationships between the variables can be generated from the studies data.

The method of pursuing the above objectives consisted of several major stages or phases of analyzing the set of four previously described case studies which document the behavior of interorganizational coalitions in community planning. During the first stage, each case was read and reread several times, with notations being made during the reading, in order to develop a sense of potential variables which might occur. After concentrating on each case study one at a time, the next major stage was a comparison of all four studies at once. This comparative analysis involved reading the studies very carefully, continuing to check back and forth between them as ideas occured in order to allow categories to evolve naturally out of the data. This phase of comparative analysis involved experimenting with different methods of noting ideas, reworking and 
reordering them, and allowing different possibilities for generalized relationships to emerge. One of the first methods used was that of placing large pieces of paper on the walls and writing on the paper any kind of variable or critical event that occurred in more than one coalition. Sometimes the existence of a particular variable in more than one coalition was apparent from the notations made during the original reading of the coalitions. At other times, discovering a critical event in one coaltion led to the examination of the other case studies and the subsequent discovery of the same previously-overlooked variable or analytical category in those other case studies. A different approach was then tried, in which all the categories or events for each coalition case study were put on numerous small cards. A total of 167 of these critical events were produced from a thorough rereading of the case studies, plus the results of the original reading phase and the previously-described attempt to write variables on paper on the wall. The events or categories for each coalition were written in an ink color different from those of the other coalitions, with one event per card, resulting in four stacks of color-coded cards representing the critical events for each coalition. Then these cards were placed on a new blank sheet of paper on the wall and rearranged several times in several different 
ways. This rearranging process was an experiment to obtain an idea of whether sequential time phases during the life of the coalition (e.g. pre-formation, during formation, project implementation) seem to be a relevant factor. The rearranging was also an attempt to obtain a sense of the degree to which all of these behavioral categories exist across coalitions (i.e. the "crosscoalitionness" of the events). Another method used during this stage of comparative analysis was to combine similar events from these cards to get a list of potential variables or analytical categories, with the time phase of each coalition's process during which each variable occurred. As a result of these different methods that were used during the stage of comparative analysis, more variables or analytical categories were identified than were reported or utilized. A complete list of all the additional identified analytical categories is attached in Appendix B.

The next major phase or stage consisted of deciding which of the possible methods described above of identifying variables seemed most useful and worth pursuing, and then reanalyzing the case studies again for new information based on this new perspective. This method is consistent with Glaser's and Strauss' theory-grounding process in which the researcher jointly collects, codes, and analyzes the data and then decides what data to 
collect next and where to find the data. (Glaser and Strauss, 1967, p. 45). The concluding stage of this study involved 1) the refinement of the descriptions of the analytical categories, and 2) the description of the generalizable relationships as possibilities for constructing hypotheses. This process was carried out without first reading other theoretical literature pertaining to coalitions in an attempt to be as uninfluenced as possible by any predetermined ideas about analyzing coalitional behavior.

REPORTING THE STUDY

The study resulted in the following four major outcomes :

1. Definition of variables or analytical categories of behavior.

2. Description of defined variables by cross-case study comparison of coalitional behaviors.

3. Identification and description of generalized relationships between the variables.

4. Suggestions for possibie hypotheses for future research.

This report of the study is organized into sections. Section II reports the first two of the major outcomes listed above. Section III consists of the third major outcome and Section IV, the fourth. Thus, the focus of 
Section II is on the identified variables or analytical categories; in Section III, it is on the generalized relationships between categories; and in Section $I V$, the focus is on future research issues.

LIMITATIONS AND DELIMITATIONS OF THE STUDY

There were certain limiting conditions under which this study was done. These constraints included:

1. The study was an individual project which the author did alone.

2. The single author worked partime on the study for about nine months.

3. The data collected by other people was, in some ways, uneven and inadequate for this particular study.

4. The choices made during the data collection concerning what information to obtain in the guided interviews may have biased the availability of variables or analytical categories available for identification during the analysis.

5. The author's previous experiences of personally being involved in coalition formation and of some familiarity with related literature may have biased the eventual selection of variables. 
The following delimitations were decided upon:

1. The study would not include a comprehensive search of related literature. Instead, some brief ideas from relevant literature would be incorporated as a comparison to the generalized relationships and possible hypothesis that had been developed.

2. Only case studies of coalitions involved in program planning/development were used. Coalitions involved in social action/conflict issues were not included in this study. 
SECTION II

ANALYTICAL CATEGORIES OR VARIABLES

The initial outcome of the comparative analysis described in the earlier chapter is the definition of the variables or analytical categories of behavior found in the case studies of coalitions. These variables are as follows:

A. The "demographic" data of the coalition, including:

1. The number of people and the number of agencies they represent who nominally form the coalition.

2. The number of people and the number of agencies they represent who are actually involved in the coalition.

3. The length of time and/or number of coalition meetings before the accomplishment of some tangible goal or objective. 4. The stimulus for forming the coaltion, which could include availability of money or an urgently-felt issue.

B. The relationships influencing the formation or operation of the coalition, including: 1. The amount of accountability to, and authority to speak for, an organized group 
that a person has in a coalition. This could range from individuals participating as "concerned citizens" who are members of groups relevant to the coalition but who do not actually represent those groups, to individuals who are officially sanctioned and empowered to commit their organization to coalition decisions (either with or without their organization's explicit approval of each decision).

2. The amount of accountability to, and authority to speak for, the coalition that individual participants have in representing the coalition to non-coalition groups. This could range from every coalition member having the freedom and autonomy to represent the coalition in outside relationships, to only selected coalition members (e.g., a chairman) having the authority to represent the coalition without the coalition's prior express approval, to no coalition member having the authority to represent the coalition without the total coalition's explicit approval in each specific instance (complete accountability).

3. The amount of previous history of working together that groups forming a coalition have. This could range from coalition member-groups 
beginning the coalition as complete strangers, to members who begin the coalition with an already-close working relationship.

4. The role of the person(s) who is the "original initiator" of the coaltion...

a. ... in his/her agency's relationship to the coalition. This could include an original initiator who was acting independently of the agency's sanction or knowledge, or an original initiator who was acting with the agency's fairly complete knowledge and approval, or an informal group who together became the original initiators independently of their agencies.

b. ... in the eventual structure of the coalition, from becoming the chairman, to becoming part of the decision-making group, to "phasing out" and not having an active role at all.

C. The interactional structure of the coalition, including:

1. The size and inclusiveness of decision-making groups in the coalition, from a small "core" working committee which excludes some members, to a number of small working committees which include all the coalstion's members, to a single small working committee which includes all the 
members of a small coalition.

2. Types of decision-making groups in the coalition, from entirely informal groups, to more formalized groups with official roles.

3. Methods of distributing the potential that exists in certain leadership coalition positions (e.g., the chairmanship) for promoting one member-group's interests over the other groups' interests. For example, these methods could include allowing one member to become a non-neutral chairman, choosing a member who had nothing at stake and was therefore neutral, choosing an outsider to be a neutral chairman, or not selecting any chairman at all.

D. The interactional processes of the coalition, including:

1. The type of decision-making process which occurred, from regular committee procedure with voting, to informal consensus agreements, to non-consensus "power plays" which result in conflicting and unilateral actions.

2. The recruitment of potential new members for the coalition, ranging from much recruitment effort through mass media techniques 
(e.g. newsletters) to informal, personal recruiting of a few selected people, to no recruitment because of not accepting any new members.

E. The funding or economic support of the coaliitself (not to be confused with funding being sought by the coalition to support the project being planned), including:

1. The amount and type needed, which could include varying amounts of coalition-members' time and varying amounts of money.

2. The manner of obtaining the funding or economic support, which could mean agency representatives contributing their own time, agencies contributing their representatives' time, and/or actual cash received to support the planning activities of the coalition.

3. The amount and type of funding or economic support actually obtained.

COMPARISON OF COALITIONAL BEHAVIORS BY ANALYTICAL CATEGORIES

The second outcome of the comparative analysis process described earlier is the further description of the defined analytical categories or variables. This description can be obtained by deriving from a 
cross-case study comparison the coalitional behaviors which are related to each category or variable. Following are these analytical categories with the related behaviors identified from the set of coalitions for each category. 
Table 1: The "Demographic" Data of the Coalitions
Variable/
I: "Com-Iine"
II: Child Dvmt.
III: Legislative
Info. Coord.
IV: Mental Health
Services System

\begin{tabular}{|c|c|c|c|c|c|}
\hline A. 1 . & $\begin{array}{l}\text { Nominal } \\
\text { number... }\end{array}$ & $\begin{array}{l}6 \text { people; } \\
6 \text { agencies }\end{array}$ & $\begin{array}{l}30 \text { people; unknown } \\
\text { no. of agencies }\end{array}$ & $\begin{array}{l}30 \text { organizations; } \\
\text { unknown no. of people }\end{array}$ & $\begin{array}{l}48 \text { people; } 25 \\
\text { organizations }\end{array}$ \\
\hline A.2. & $\begin{array}{l}\text { Actual } \\
\text { number... }\end{array}$ & $\begin{array}{l}6 \text { people; } \\
6 \text { agencies } \\
\text { (same as above) }\end{array}$ & $\begin{array}{l}5 \text { people; } 5 \text { agen- } \\
\text { cies on "core" } \\
\text { committee }\end{array}$ & $\begin{array}{l}12-15 \text { organizations; } \\
\text { unknown no. of people }\end{array}$ & $\begin{array}{l}8 \text { people from } 7 \\
\text { agencies first; } \\
\text { then about } 48 \\
\text { people from } 25 \\
\text { organizations }\end{array}$ \\
\hline A. 3. & $\begin{array}{l}\text { Length } \\
\text { of time... }\end{array}$ & $\begin{array}{l}9 \text { monthly mtgs } \\
\text { until formal } \\
\text { proposal approved }\end{array}$ & $\begin{array}{l}\text { I } 1 / 2 \text { mo. of wkly } \\
\text { or twice-wkly mtgs } \\
\text { until proposal } \\
\text { submitted }\end{array}$ & $\begin{array}{l}\text { I mo; several (?) } \\
\text { mtgs until project } \\
\text { became operational }\end{array}$ & $\begin{array}{l}3 \text { mo; } 4 \text { large group } \\
\text { mtgs, some committee } \\
\text { mtgs, 2-day work } \\
\text { conference until } \\
\text { drafts produced }\end{array}$ \\
\hline A. 4. & $\begin{array}{l}\text { Stimulus } \\
\text { for form- } \\
\text { ing }\end{array}$ & $\begin{array}{l}\text { Mutually comple- } \\
\text { mentary needs; } \\
\text { agency boards } \\
\text { felt pressure } \\
\text { from clientele to } \\
\text { provide service }\end{array}$ & $\begin{array}{l}\text { Sudden availabil- } \\
\text { ity of Fed. money } \\
\text { for funding a pro- } \\
\text { posal quickly }\end{array}$ & $\begin{array}{l}\text { I person/agency } \\
\text { needed support for } \\
\text { own project; thot } \\
\text { others might need } \\
\text { similar support }\end{array}$ & $\begin{array}{l}\text { Non-urgent availa- } \\
\text { bility of Fed. funds, } \\
\text { plus momentum from } \\
\text { much previous plan- } \\
\text { ning and need }\end{array}$ \\
\hline
\end{tabular}

Table 1. This table illustrates that, except for one instance, the actual number of participants in coalitions tends to be much smaller than the nominal number originally forming them. The length of time until some tangible goal was achieved varied from a minimum of 1 month to a maximum of 9 months. There was also a wide variety of stimuli for forming the coalition. 
Table 2: The Relationships Influencing the Coali-

tions' Formation or Operation
Variable/
I: "Com-Line"
II: Child Dvmt.
III: Legislative
IV: Mental Health Services System

B. 1 .

Accountability/ Agency reps ea. authority to group... had to report back to own brds w/ea. major decision before making any commitments

\section{B.2.}

Accountability/Much autonomy; authority to coalition... members individually \& unofficially contacted School Board members informally
B.3.

Previous history...

4 agencies had long-time good working relationships; 2 were newcomers

B.4. Original initiator

B.4.a. role in tionship agency's rela-
1 agency board member acting $w /$ board knowledge and approval
Virtually no accountability but much authority of people on "core" were asked to rubber stamp project committee; boards
Unclear--some may have had authority, others apparently didn't; none were very accountable, apparentiy
Much independence, little accountability to agency; possibly not much authority as representativs, either

Much autonomy tak- Much autonomy and en unilaterally by authority taken by one member, but informal committee coalition did not give authority for this

Unknown; some of original 30 people undoubtedly had previous history

Much previous and current working together

Unclear--officers probably had some authority and were accountable; rest of group perhaps acted as a unit?

5-6 yrs of ongoing working together on this issue
1 person acting quite independent-pendently of the agenly w/only the board's "interest" sanction

as sanction
Inter-agency informal group acting unofficially \& fairly $N$ agencies' sanction 


\begin{tabular}{|c|c|c|c|c|}
\hline $\begin{array}{l}\text { Variable/ } \\
\text { Category }\end{array}$ & I: "Com-Line" & II: Child Dvmt. & $\begin{array}{l}\text { III: Iegislative } \\
\text { Info. Coord. }\end{array}$ & $\begin{aligned} & \text { IV : } \text { Mental Health } \\
& \text { Services System }\end{aligned}$ \\
\hline $\begin{array}{l}\text { B. } 4 . \text { b. role in } \\
\text { eventual coali- } \\
\text { tion structure }\end{array}$ & $\begin{array}{l}\text { Became ongoing } \\
\text { (but unofficial) } \\
\text { chairman of work- } \\
\text { ing committee }\end{array}$ & $\begin{array}{l}\text { Became member of } \\
\text { core working com- } \\
\text { mittee; actively } \\
\text { advocated for own } \\
\text { agency's interests } \\
\text { in conflicts }\end{array}$ & $\begin{array}{l}\text { Was active member of } \\
\text { lst working committee; } \\
\text { then had formal posi- } \\
\text { tion in decision-mak- } \\
\text { ing Exec. Council }\end{array}$ & $\begin{array}{l}\text { Became members of work- } \\
\text { ing committees; } 1 \text { of } \\
\text { group became coalition } \\
\text { chairman, but rest did } \\
\text { not have any formal } \\
\text { positions ("melted in" } \\
\text { to coalition) }\end{array}$ \\
\hline
\end{tabular}

Table 2. From this table it seems clear that, in most of these cases, the coalitions were established by people with some history of good working relationships with each other. Further, apparently these coalition members gave each other much autonomy within the coalition. However, the amount of autonomy or authority given to coalition participants by the groups they represented varied greatly. The data in this table would also strongly suggest that a coalition is originally initiated by an individual (or perhaps a small group) under a variety of kinds of sanctions from her/his official organization, and that this original initiator tended always to become part of the coalitions' small decision-making group. 
Table 3: The Interactional Structure of the Coalitions

Variable/ I: "Com-Iine" I'I: Child Dvmt. III: Iegislative Info. Coord. Mental Health
Category

C.1. Decision- All 6 members were 5 reps from 5 making groups' part of single agencies became size and decision-making/ inclusiveness working group

"core" working committee; original 30-person group made no decisions

C.2. Types of Informal workdecision-making ing group first; groups later had Exec. Board \& Project Director

Informal working "core" group; never became formalized into any structure
Self-selected group of 7 people from 5 agencies became unofficially the decision-making/ working committee
Competitive need for coalition; no effective means for reducing com- petition yielded much continual conflict \& promo- tion of self-in- terests
C.3. Distri- bution of interest- promoting potential
Complementary needs of all coalition; chrman was original initiator from one agency

Informal working group first; later had Exec. Committee and Steering Comm.

Chose outsider $\mathrm{w} / \mathrm{no}$ vested interest to be chrman; became neutral coalition, not advocate for any group's interests
Unofficial self-selected group of 8 people from 7 agencies were first steering committee; later 48-person group had officers and 8 working committees for decision-making

Informal steering committee first; later had chrman, vice-chrman, and 8 official working committees (each with chairman)

Chrman was competent \& neutral member (his agency had no stake); also had 8 committees for decision-making

Table 3. This table indicates the consistency with which coalitions' decision-making groups are small and originally informal or unofficial, although later they may become formalized. The chairman tends to be neutral (or at least non-threatening); in one case no effective way was found to neutralize the ongoing conflict over promoting self-interests. 
Table 4: The Interactional Processes of the Coalitions

Variable/ I: "Com-Line" II: Child Dvmt. III: Iegislative
Category

\section{D.1. Type Regular commit- of decision- tee procedure $w /$ making process voting}

\section{D.2. Recruit-} ment of potential members

Informal personal recruitment of a few selected people
Unilateral power plays; voting by polarized commit. tee

Unclear--probably no recruiting done

Active impersonal recruitment through newsletters of member organizations and. other mass media
Informal consensus agreement in working committee
Unknown in informal steering committee; regular voting in formalized structure

Unclear--probably unsystematic and informal recruiting

Table 4. The data in this table would indicate that coaljtion members use a range of processes-from formal and impersonal to informal and personal, and from conflict to consensus-in their interactions within and outside the coalition. It is interesting to note that one coalition had a formal decision-making process but an informal recruiting process, while another one used informal processes in decision-making but impersonal processes in recruiting new members. 
Table 5: The Funding or Economic Support of the Coalitions

\begin{tabular}{|c|c|c|c|c|}
\hline $\begin{array}{l}\text { Variable/ } \\
\text { Category }\end{array}$ & I: "Com-Line" & II: Child Dvmt. & $\begin{array}{l}\text { III: Legislative } \\
\text { Info. Coord. }\end{array}$ & $\begin{aligned} \text { IV: } & \text { Mental Health } \\
& \text { Services System }\end{aligned}$ \\
\hline $\begin{array}{l}\text { E.I Type \& } \\
\text { amt of fund- } \\
\text { ing needed }\end{array}$ & $\begin{array}{l}\text { Staff time from } \\
\text { agencies }\end{array}$ & $\begin{array}{l}\text { Staff time from } \\
\text { agencies }\end{array}$ & Staff time & $\begin{array}{l}\text { Staff time; money to } \\
\text { travel to model } \\
\text { program }\end{array}$ \\
\hline $\begin{array}{l}\text { E.2 Manner } \\
\text { of obtaining } \\
\text { funding }\end{array}$ & $\begin{array}{l}\text { Agencies suppor- } \\
\text { ted coalition and } \\
\text { contributed staff } \\
\text { time }\end{array}$ & $\begin{array}{l}\text { Agencies cooper- } \\
\text { ated \& apparently } \\
\text { contributed staff } \\
\text { time }\end{array}$ & $\begin{array}{l}\text { Unclear--apparently } \\
\text { people individually } \\
\text { contributed their own } \\
\text { time }\end{array}$ & $\begin{array}{l}\text { Agencies contributed } \\
\text { staff members' time; } \\
\text { NIMH grant for tra- } \\
\text { vel money }\end{array}$ \\
\hline $\begin{array}{l}\text { E.3. Type \& } \\
\text { amt of fund- } \\
\text { ing obtained }\end{array}$ & Enough staff time & Enough staff time & $\begin{array}{l}\text { Unclear--possible not } \\
\text { enough time }\end{array}$ & $\begin{array}{l}\text { Enough staff time \& } \\
\text { money }\end{array}$ \\
\hline
\end{tabular}
ing obtained

Table 5. The above table suggests that, for the most part, the coalitions in this study were supported by staff people's time; there was only one case in which some money was needed in addition to time. Further, evidently this time for people to participate in the coalition was usually contributed by the agencies or organizations involved. The table shows possibly only one coalition operating just on individuals' contributions of their own time. 


\section{SECTION III}

\section{GENERALIZED RELATIONSHIPS}

The third outcome of this study is the identification and description of generalized relationships between the variables. From the descriptions of coalitional behaviors in terms of analytical categories in the previous section, the following generalized relationships appear to emerge:

1. A relationship between the nominal number of organizations composing the coalition, the actual number of organizations involved, and the size and inclusiveness of the decision-making groups (Variables A.1., A.2., and C.1.). An extremely small coalition can incorporate all its members in a decision-making group, but larger coalitions tend to have small selective decision-making groups which exclude some members.

Coalition I: "Com-Line"

There were only six nominal and actual members of this coalition, all of which were part of the decision-making group.

Coalition II: Child Development

The original 30-person group quickly "collapsed" into a small "core" group of five people, and the large group effectively ceased to function. 
Coalition III: Legislative Information Coordination Project

A planning committee of seven people from five agencles became the decision-making group, excluding the rest of the approximately fifteen agencies with an unknown number of representatives. Coalition IV: Mental Health Services

This coalition is a possible exception because It apparently spread decision-making throughout eight formal committees; however, the eight committee chairmen plus the coalition chairman and vice-chairman could be considered to be the small decision-making group, since they evidently performed much of that function.

2. A relationship between the amount of member organizations' complementary needs for the coalition compared to the amount that their needs for the coalition are competing (plus any time constraints), and the inclusiveness of the decisionmaking group (Variables A.3., A.4., C.1., and C.3.). Non-complementary needs (i.e., needs that were in conflict with each other) together with much time pressure, seemed to result in an exdlusive decisionmaking group instead of a more inclusive sharing of decision-making. 


\section{Coalition I: "Com-Iine"}

All the members needed each other (none of them could do the project without the others), so their needs were almost completely complementary. Each could provide some necessary time, credibility, knowledge, ideas, or access to important groups. The decision-making was shared among all the members.

Coalition II: Child Development

The only mutual need that the members seemed to share was perhaps a requirement to demonstrate to a federal agency that a coordinated planning process had occurred. Other than that, the members' needs were practically mutually exclusive. There was also an extreme amount of time pressure, and both these factors appear to have resulted in a small exclusive decisionmaking group.

Coalition III: Iegislative Information Coordination Project

The original initiator was under much pressure to make the project operational in about a month's time. Further, the planning committee members' need for the coalition did not seem to be mutually shared by the rest of the members. The decision-making group was, for all intents 
and purposes, the planning committee, which excluded most of the members.

Coalition IV: Mental Health Services

This coalition was not operating under an urgent time deadline, and most of the participants could provide some needed resources, access to important groups, or knowledge/expertise that the coalition would otherwise not have had. Even though this coalition was large (48 people, 25 agencies), the decisionmaking was inclusive of most members instead of being completely exclusive. Therefore, little time constraints and many complementary needs appeared to be related to sharing the decision-making.

3. A relationship between the amount of member organizations' conflicting needs instead of complementary needs for the coalition, the distribution of potential for promotion of self-interest, and the type of decision-making process (Variables A.4., C.3., and D.1.).

Coalition I: "Com-Line"

Even though the chairman was from a non-neutral agency (which had a vested interest in the coalition's outcome), apparently the great amount of 
complementary needs of each agency for the others kept confiicts over promotion of selfinterests almost non-existent.

Coalition II: Child Development

In this coalition the great amount of conflicting needs of the member organizations was coupled with the non-existence of any effective means of distributing the potential for promoting self-interests. These two factors together contributed to continual conflict and unilateral power plays in the working committee, with one faction of the polarized working committee voting in the absence of the other faction to take action that was opposite to the self-interests of the absent faction.

Coalition III: Iegislative Information Coordination Project

By choosing a neutral outsider to be the chairman, the coalition apparently neutralized much potential for conflict over promoting selfinterests, and the working committee was able to operate by informal consensus agreement. Coalition IV: Mental Health Services The apparent existence of a greater amount of complementary than competing needs of member organizations, together with selecting a neutral 
chairman and sharing the decision-making among eight working committees, appeared to allow the coalition to establish a consensus-by-voting process.

4. A relationship between the informal decisionmaking structure and any formal structure that was created (Variables B.4.b., C.I., and C.2.). The informal decision-making structures were established first, and the formal structures that evolved later in the coalition process tended to overlap or even be the same as the original informal structures. Coalition I: "Com-Line"

The original decision-making group was an informal one composed of six members, one from each agency. When the project was ready to become operational, one of these members became the Project Director and the others became part of the Executive Board. The remainder of the Executive Board members were representatives of the same six agencies, thus translating almost exactly the original informal decisionmaking group into the formal decision-making structure.

Coalition II: Child Development

In this coalition a formal decision-making 
structure never emerged. One might guess at possible reasons for this fact, perhaps including the extremely limited time and the existence of a continual conflict (instead of consensus) decision-making process.

Coalition III: Legislative Information Coordination Project

The informal decision-making working committee of seven representatives from five agencies became the Executive Committee when the coalition formalized itself. The only addition to the decision-making group was a neutral outsider who was chosen by the informal working committee to be the coalition chairman. After the coalition became formalized, the rest of the organizations were members of the "Steering Committee," but in practice the Executive Committee apparently continued to be the decisionmaking body.

Coalition IV: Mental Health Services

The process of the informal structure becoming the formal siructure was not as complete in this coalition as in other coalitions. Before the official formation of this coalition, the original informal eight-member decision-making 
"steering committee" chose one of their members to be chairman and an outsider to be vice-chairman of the soon-to-be established coalition. When the coalition formalized, the already-selected chairman and vice-chairman were accepted by the total group to hold those offices. However, none of the remaining seven of the original informal steering committee members became a chairman of any of the eight formally-established working committees. Therefore, the formal decision-making structure overlapped but was only partially the same as the original informal structure. 
SECTION IV

\section{ISSUES FOR FUTURE RESEARCH}

The final outcome of this study is the suggestion of possible hypotheses which might be fruitful for carrying out future research. Based on the foregoing identification of analytical categories and the generalized relationships between those categories, the following hypotheses concerning the behavior of organizational coalitions would appear to be plausible possibilities:

1. Coalitions will, by a variety of processes, have a "core" decision-making group that will probably not be larger than ten members, and that any additional members over that number will effectively be excluded from the actual decisionmaking process. This proposition seems consistent with the ideas found in research literature. For example, James D. Thompson states that if power in a coalition is widely distributed, then an "inner circle" develops which conducts the coalition's business. He explains that these people represent (and are trusted by) different major segments of the group; and whether they act formally or informally, they reflect the power of those for whom they speak. An organization with 
with dispersed bases of power is immobilized unless an effective inner circle exists. (Thompson, 1967).

2. The more that member organizations' needs for the coalition are in conflict rather than complementary, together with the more that time pressures are present, the more that the decisionmaking groups will be a limited, exclusive body instead of a widely-shared inclusive group.

3. The more that member organizations' needs for the coalition are in conflict rather than being complementary, the more it is necessary to distribute and neutralize in some way the potential for one group to promote its own interest at the others' expense in order for the coalition's decision-making process to be a consensus process (e.g., voting) instead of continual unresolved conflict.

The above two propositions are concerned with the effect of member organizations' needs being more in conflict/competition than complementary. Related to these propositions is Warren's idea of an "issueoutcome interest," in which organizations are assumed to tend to operate in their own interests -that is, to enhance or protect their own organizational domains. Converging issue-outcome interests 
will probably result in a collaborative or cooperative pattern of decision-making; divergent issue-outcome interests will probably yield a contest pattern of decision-making (Warren, 1971). Reid (1969) proposed the following formulation regarding interdependence among organizations: "the greater the similarity of mutually dependent goals, the greater the interdependency and hence the greater the extent and stability of exchanges."

4. In most organizations the formal and informal communications/decision-making structures co-exist side by side. In a coalition, instead of existing concurrently with each other, the informal structure will be created first and will establish the coalition, and any formal structure that may evolve later will consist of essentially the same participants as the original informal structure. Therefore, the informal structure (instead of co-existing) will be replaced with a formal system composed of the same decision-makers.

This proposition is quite different from the usual assumptions regarding the existence of co-existing but separate formal and informal authority structures. Rush, in reviewing Rensis Likert's ideas about the nature and functioning of organizations, 
shows Likert's view that formal, designated authority is hierarchical and that informal authority is the "real" authority. (Rush, 1969). The above proposition generated from this study indicates that different assumptions concerning the formal and informal communications/decisionmaking structures may be necessary for coalitions than for formal organizations. If such is the case, this could well be one of the significant differences between coalitions and formal organizations.

\section{FURTHER ISSUES FOR POSS IBIE EXPLORATION}

This study has Identified other issues which could be possibilities for future exploration but which did not emerge clearly as generalized relationships from the data avaliable in this study. These issues might include:

1. More complete definition of the role and effects of the original initiator. Given the facts that, in all the cases in this study, the original initiator became part of the coalitions decision-making group, and that the initiating was done under a variety of kinds of circumstances and sanctions from his/her formal agency, it seems reasonable to expect that these circumstances will have an effect on the coalition's outcomes or 
functioning. (See Table 2).

2.' Possible relationships of the coalition's funding or economic support to other variables. It would perhaps be useful to know whether individuals contributing their own time compared to agency's contributing staff time makes any difference in the coalitions outcomes. (See Table.5).

3. Possibie relationships between coalition members' authority/accountability to their own agencies and other variables. In this study there was a wide variety of kinds and amounts of accountability to their own agencies that members expressed. (See Table 2). It seems very possible that this variable may have made a definite difference in the differential effects of the various coalitions.

4. Possible relationships of the stimulus for forming the coalition to other variables. This variable (See Table 1) seems related to both the interactional structure and the interactional processes of the coalition. 


\section{BIBLIOGRAPHY}

1. Evan, William M., "The Organization-Set: Toward a Theory of Interorganizational Relations," Approaches To Organizational Design, James Thompson (ed.), Univ. Of Pittsburgh Press, 1966.

2. Glaser, Barney, and Anselm Strauss. The Discovery of Grounded Theory. Chicago: Aldine Publishing Co., 1967.

3. Levine, Sol, Paul E. White, and Benjamin D. Paul. "Community Tnterorganizational Problems in Providing Medical Care and Social Services." Readings in Community Organization Practice, Kramer and Specht (eds.), Englewood Cliffs, N.J.: Prentice-Hall, Inc., 1969.

4. Rush, Harold M.F. Behavioral Science: Concepts and Management Application. New York: National Industrial Conference Board, Inc., 1969.

5. Reid, William J. "Inter-Organizational Coordination in Social Welfare: A Theoretical Approach to Analysis and Intervention." Readings In Community Organization Practice, Ralph Kramer and Harry Specht (eds.), Englewood Cliffs, N.J.: Prentice-Hall, Inc., 1969.

6. Sellitz, Claire, Marie Jahoda, Morton Deutsch, and Stuart Cook. Research Methods in Social Relations. New York: Holt, Rinehart, and Winston, 1959.

7. Thompson, James D. Organizations In Action. New York: McGraw-Hill Co., 1967.

8. Warren, Roland. Truth, Love, and Social Change. Chicago: Rand McNally, 1971. 
APPENDIX A: Interview Guideline

\section{THE FOCUS OF THE CASE STUDY}

The case study will focus around three major concerns:

1. The Developmental Pattern. How the coalition was formed and around what issues. What "stake" or interest the organizations had in the issue.

2. The Structure of the Coalition. By the structure we are referring to the pattern or relationships between the member organizations. For example, relationships may be very informal where all the organizations jointly participate in decisions to a more formal pattern where members must clear with their constituency before some decision is made.

3. The Deciston-Making Characteristics. How does the coaltion go about making decisions and what affect, if any, does the decision of the coalition have on its member organizations.

COLIECTING THE DATA

The data collection process should attempt to get an accurate description of the history and development of the coalition. However, in order to provide for commensurate information in all of the case studies we want to be sure to get information on the following topics in some depth:

1. Around what issue or issues was the coalition initially formed?

Was the issue a "hot" or controversial one? Was the issue specific and clear to everyone or rather ambiguous?

2. How did the coalition get formed?

Was there one person who, for example, talked with the members first and then called the group together?

Did someone just convene a meeting?

Did a small group meet first and then add others later?

3. What "stake" or interest did the members have in the coalition?

What did the members stand to gain or lose?

Did some members have more power or investments in the coalition than others? 
4. How accountable were the members of their constituency?

Did people have to "clear" with their constituencies before decisions could be made?

5. How did the coalition organize itself for decisionmaking?

Did they have a series of random and informal meetings?

Was there some structure -- a chairman; were minutes kept; an executive committee?

Were there realiy one or two people who managed the affairs of the group?

Who did the convening?

6. Were there any conflicts or arguments between the members?

Were there any disagreements? How were they settled?

Did anyone pull out or drop out?

7. Over time, did new issues emerge, or did the group stick close to its initial purpose?

Did anyone try to change the focus of the coaltion?

If new issues were introduced, what happened?

8. What effect, if any, did the decisions made in the coalitions effect the member's own organization?

Did any of the members try to go back to their respective organizations and try to get them to change some policy, program, or procedure?

In addition be sure to get the following kinds of information.

(a) The time period spanned -- when it began and when it dissolved.

(b) The organizations represented on the coalition, who represented them, and the job categories (i.e., the director of an organization, vs. the staff).

(c) Specific dates -- or if that is not possible, approximate dates -- of initial meetings, events, of key actions. In short we not only want to know what took place, but when it took place. 
APPENDIX B: List of Additional Tdentified Variables or Analytical Categories

Goals or purposes of coalition

Selection (or non-selection) of chairman or director Meeting time, place, agenda (subsequent to first meeting) Amount of recruitment of potential new members Amount of communication with the general public Means of communication with the general public Operational tasks for the proposed project/program Type of formalized coalition structure Amount of funds or resources needed and/or obtained Source and type of resources needed and/or obtained Distribution of funds or resources Amount of authority/accountability given to coalition by participants

Relationship to "parent" or member groups of coalition individuals

Operational procedures and objectives of project Location (physical space) of coalition Staffing/manpower of project/program Relationship to other non-coalition groups Methods and criteria for recruiting potential new members Initiating discussion/meeting to explore coalition idea Format for initiating coalition exploration Criteria and method for inviting original ("core") members Amount of agency board involvement Purpose/function of coaltion's meetings Coalition formalizing into legal organization Criteria for allowing attendance at coalition meetings "How fast to move" (deadlines, etc.) Amount of involvement of non-coalition "target group" Organization and administration of project or program Location and arrangement of project or program Search for new ideas and adaptable programs Amount and type of input by coalition members at meetings Amount of work done outside coalition meetings Type and urgency of stimulus for forming coalitions Format of coalition meetings 